\title{
STUDIES:
}

\section{Educating the "New Man" in Italian Schools during the Fascist Era. Children's Education through Traditional and Totalitarian Models in Images and Texts of Schoolbooks}

\author{
Simonetta POLENGHI
}

\section{ARTICLE INFO \\ Article history: \\ Received 5 February 2020 \\ Accepted 26 April 2020 \\ Available online 31 July 2020 \\ Keywords: \\ Italian Fascism; school textbooks; the Fascist "new man"/"new child"; progressive education; Fascist educational models}

S. Polenghi
Catholic University of the
Sacred Heart •
Department
of Education $•$
Largo A. Gemelli 1
20123 Milano $•$
Italy $\bullet$
simonetta.polenghi@unic
att.it

\begin{abstract}
Educating the "New Man" in Italian Schools during the Fascist Era. Children's Education through Traditional and Totalitarian Models in Images and Texts of Schoolbooks
\end{abstract}

Fascism used different tools and media to educate Italians to be good Fascists, and to present the myth of the "new man". This myth had a number of different nuances during the twenty years of the regime. The strong educational aim of Fascism pervaded the entire life of Italians and assigned great importance to the education of children and young people. Schools were therefore given a significant role in this process, which grew in intensity during the thirties, with the Empire and the conquest of Ethiopia. School textbooks, with their images, are relevant sources for examining this process. Thanks to the extensive work in revising school textbooks undertaken by the Commission, which had been established by the minister Giovanni Gentile in 1923 and was chaired by Giuseppe Lombardo Radice, only the best books, which included the notion of progressive education and a modern idea of the child, could be published. The search for "the Fascist book" then began, but it was only in 1930 that the State Fascist textbooks replaced by law the previous ones. Nonetheless, an examination of the text and images of various State textbooks reveals a complex mix of traditional educational messages, centred around the Catholic faith, patriotic values and il Duce's exaltation. It has been noted that the "new man" was initially an anti-liberal and subsequently a "mass-man" [uomo-massa], with no individual identity. Examination of the State textbooks, however, also reveals messages, which were sometimes contradictory (Christian peace and Fascist war, for example). The importance of the family, constantly underlined, undermined the "mass-man" messages. Traditional rural values coexisted with the spirit of modernization.

This article shows how some Fascist educational messages were coherent with traditional ones, and were therefore probably more easily accepted, whereas others were typically Fascist; and how the image of the new child changed. 


\section{Introduction}

Fascism used different tools to educate Italians to be good Fascists, ranging from parades to cinema, sport to newsreels, exhibitions to newspapers, and architecture to radio. The myth of Mussolini was constructed and symbols were used to elicit emotions (Gentile, 1990; 1993). The school system was gradually involved in this process, its engagement increasing in intensity during the thirties (Ostenc, 1980; Betti, 1984; Charnitzky, 1994). School textbooks, as well as exercise books, serve as relevant sources for examining this process, with historians drawing attention to how they shed light on it. However, if we focus on school textbooks alone, we see that during the twenties the process of the "fascistization" of schools was slower and much less pervasive than one might expect. It was not until 1930 that school textbooks were totally unified under a Fascist stamp. We will examine the main Fascist State textbooks to detect their degree of adherence to the idea of the Fascist "new man" and their relation to previous schoolbooks and educational models. We will examine images, too, to check their meanings and their matching to the messages of the texts.

\section{The Fascist "new man": A multifaceted concept}

Emilio Gentile has clearly shown that as Fascism constituted a revolution, it depended on the building of a new man. Some traits of this new man derived from old traditions (the ethical Roman legionary and the good peasant); some traits were new, responding to the needs of modernity, of anti-middle-class feelings, and of anti-liberal ethics. Militarism, linked to the traditional legacy of the Roman Empire and the fresh memories of WWI, was a typical characteristic of the new man values. The idea of regeneration featured prominently. In this respect, WWI and the Risorgimento (the re-birth of Italy during decades of struggle against foreign dominions with the aim of unification) were presented as the origins of the Fascist revolution. Ultimately, the regeneration of Italians and the value of the soldier-citizen favoured sport, gymnastics, an attitude of virile masculinity and the myth of youth (Gentile, 1990; 1993; 2002; La Rovere, 2002; Baris, 2011).

The rebirth of the Italian spirit was strongly connected with youth: Fascism was born as a movement of young people and the new man was young. Giovinezza [Youth] was the anthem of the Black Shirts and the symbol of the Fascist boy was Balilla, the boy who apparently started the insurrection of Genoa against the Austrians in 1746 by throwing a stone at the Habsburg soldiers during the War of Austrian Succession (La Rovere, 2002, p. 53; Malvano, 1994, pp. 311-314). Youth organizations, starting from Opera Nazionale Balilla, set up in 1926, rapidly grew and permeated life outside school (Betti, 1984).

Looking at education, we can use Pazzaglia's analysis (Pazzaglia, 2003) to see exactly how the new man was presented to the young generation. Pazzaglia identifies four periods in the construction of the educational model of the new man:

1. 1921-25: Mussolini's rise to power. In this phase Mussolini himself was the new man. His biographies, which depicted him as a hero, played an important role in this. The aviator was a symbol of the modern hero and superior man, a dominator who rose above the lowly herd, and Mussolini liked to be represented as an aviator. 
2. 1926-29: The birth of the dictatorship. In this phase the philosopher Giovanni Gentile's influence was strong. The initial revolutionary spirit subsided, the ethical State viewed from an idealistic perspective becoming the main protagonist of educational discourse, with its exaltation of the State and its moral and religious functions. The virtues of the new man were sacrifice, devotion, discipline, and faith.

3. 1930-35: The years of consent. The new man took on the clear traits of the "mass-man" [uomo-massa], who had no particular personality of his own, but a collective identity. Sport was seen as a tool to educate, instilling order and discipline.

4. 1936-43: The final dictatorship. In the years of the Second Italo-Ethiopian War, of the Rome-Berlin Axis, of the anti-Jewish laws, and of WWII, the educational discourse was heavily imbued with totalitarianism, colonialism, militarism and racism. The new man was born to be a soldier.

Thus, there was an evolution (or involution) in the idea of the new man during the Fascist era. Ascenzi and Sani have recently examined the evolution of the image of the new child on the covers of a wide selection of school exercise books. The images of children on these covers present the glorification of discipline, of a sense of duty, a spirit of sacrifice, of blind obedience and respect for hierarchies; but until 1930 one also notices an educational approach that seems to favour the dimension of play, of youthful enthusiasm and committed participation, that resembles the joyful image of the child one finds in the best schoolbooks of the time (Image n. 1). From the mid-1930s onwards, the covers show an increasing reference to more virile, warlike virtues (the myth of "heroic youth") and to an exaggerated nationalism, racial superiority and, ultimately, to the real glorification of war (Image n. 2) (Ascenzi and Sani, 2018). In the exercise books examined by Morandini, the drawings of children also show Roman symbols, weapons and the ever-present Balilla (Image n. 3) (Morandini, 2019).

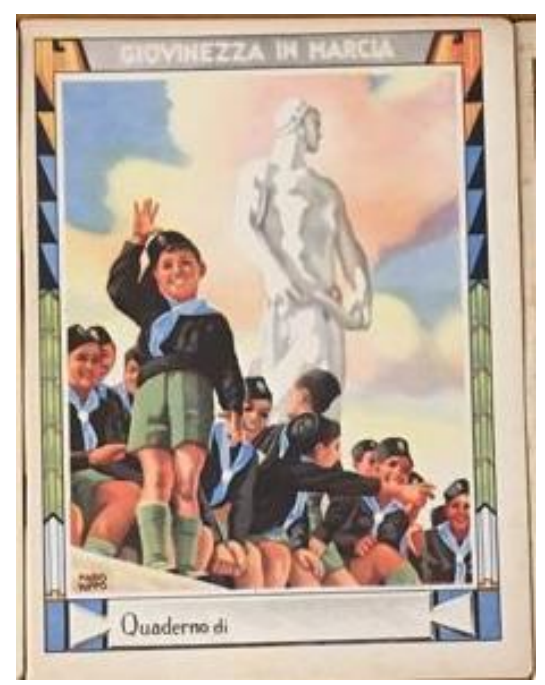

Image $\mathrm{n} .1$

Ascenzi and Sani, 2018, p. 264.

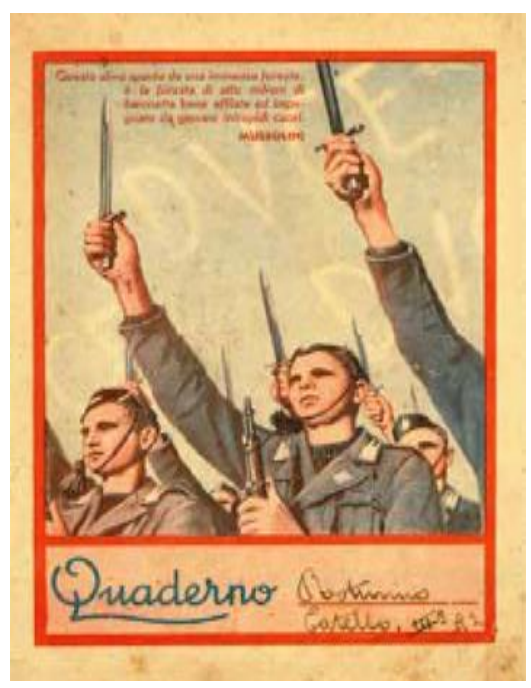

Image n. 2

Ascenzi and Sani, 2018, p. 272.

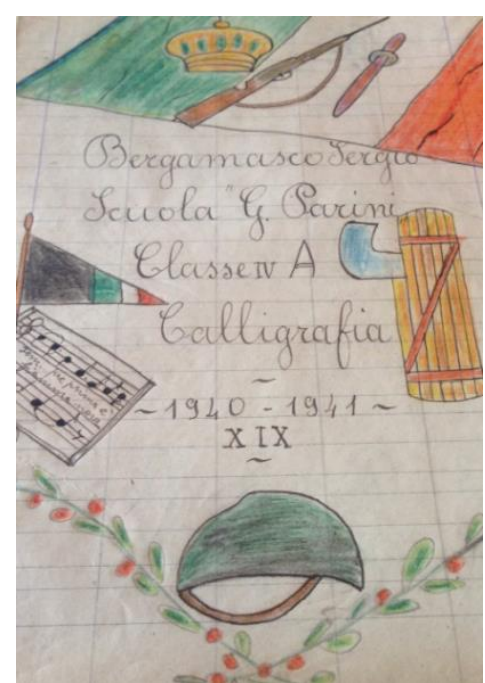

Image n. 3

Morandini, 2019, p. 391. 


\section{Educating the new Italian child through school textbooks}

The history of school textbooks in the Fascist era has been analyzed by Ascenzi and Sani, who carefully reconstructed the laws and State rules that shaped this sector (Ascenzi and Sani, 2009. See also Montino, 2005; 2007; Fava, 2008; Morandini, 2008. On the previous period, see Barausse, 2008). They also published the minutes and decisions of the National Commissions for the evaluation of school textbooks (1923-28) (Ascenzi and Sani, 2005).

As Premier, Mussolini appointed the famous Neo-Idealistic philosopher Giovanni Gentile as Minister of Education. Over the course of a few months, between 1923 and 1924, Gentile changed the Italian school system with the so called "Gentile Reform" (Ostenc, 1980; Charnitzky, 1994). According to the Neo-Idealistic perspective, teaching was the meeting of two free souls and the teacher had to be free in his/her methods. School textbooks played a key role in the implementation of Gentile's reforms. Only by changing them could he really change teaching. Convinced of this, he appointed his friend Giuseppe Lombardo Radice, Professor of Educational Theory at the University of Catania, as Ministerial Secretary of elementary schools.

Lombardo Radice wrote new school programs, with new subjects: drawing, religion and regional folk culture, including dialects. He gave space to arts, poetry, and singing. The most important pedagogist of Neo-Idealism, Lombardo Radice was also closely aligned to progressive education. He admired Pestalozzi, Froebel, and J. P. Richter, seeing the child as a free, spontaneous being, with an innocent soul, full of imagination, and loving magic. In 1923 Gentile appointed a National Commission, chaired by Lombardo Radice, to evaluate all school textbooks. In 1924 Lombardo Radice resigned from his ministerial appointments, having developed a strong anti-Fascist belief, but he had managed to complete this great undertaking, and judge hundreds of books. Out of 459 reading books, only 32 passed his tests and were praised for their pedagogical and artistic values, expressive of progressive education; 222 were failed while the others were required to be revised before they could be published. This Commission became a cultural filter and favoured a new image of the child: innocent and spontaneous. The literary models of the Commission were Cuore [Heart] and Pinocchio (Ascenzi and Sani, 2005, p. 8; Bacigalupi and Fossati, 1986, p. 154). According to the Commission: "The reading school textbook must be beautiful and good, entertaining, organic and lively for its first aim is to educate" (Fava, 2008, p. 16).

The Commission strongly criticized moralism and erudition, and praised books with original stories, that paid attention to the psychology of the characters, with moderate rather than exaggerated feelings. It was also very attentive to the beauty of a book, of its images as well as of the style of its language. The Commission's evaluation had a very strong impact. Many old publishing houses went through a period of difficulty, and even closed down, with new ones emerging in their place (Chiosso, 2013; Turi, 1995, p. 448; Oliviero, 2007, pp. 87-99; Galfré, 2005). New books were written, by Lombardo Radice's followers, for elementary schools, and by Gentile's followers for high schools (Chiosso, 2006, pp. 180-191).

This encouraged the circulation of very good school textbooks, clearly not Fascist, original and fresh, where the children depicted were real: spontaneous and lively, sad and cheerful 
(Chiosso, 2006; Bacigalupi and Fossati, 1986; Ascenzi and Sani, 2005). They were often represented as children of middle-class families. See for instance some of the images from two of the best reading books, approved cum laude: Allegretto e Serenella (1920), by Virigilio Brocchi, a socialist teacher and writer, illustrated by Enrico Mario Pinochi (image n. 4) and Duilio Cambellotti (image n. 5), a famous artist, with a delicate and elegant style, and in later editions by another highly accomplished artist, the Russian Vsevelode Nicoùline; and Serenità [Serenity] (1915) by Lucia Maggia, a teacher, poet, and writer for children, illustrated by the same brilliant illustrator, Enrico Mauro Pinochi (image n. 6). These books, being approved cum laude, enjoyed a wide success and were used all over in the country (Ascenzi and Sani, 2005).
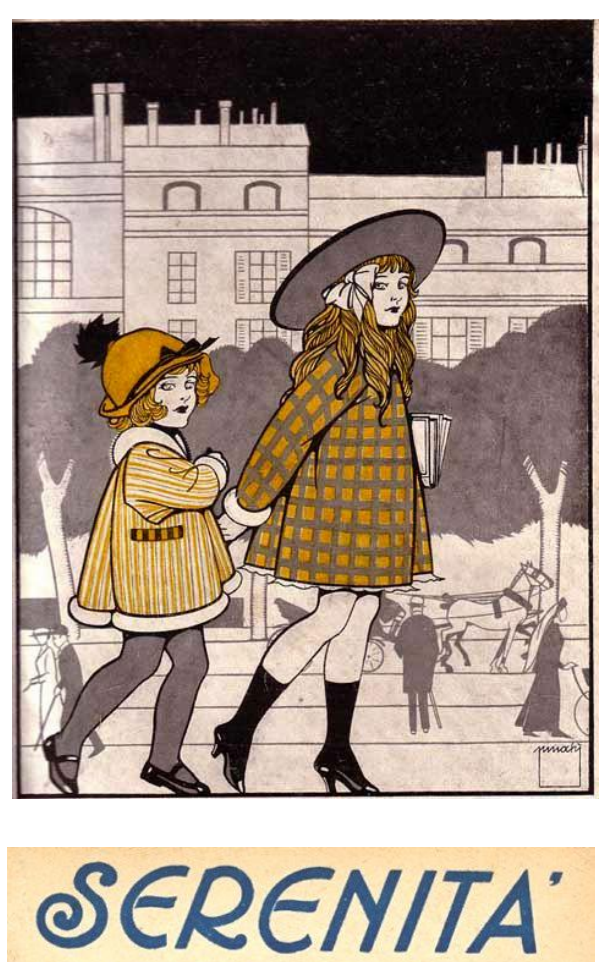

NUOVISSIMO LIBRO DI LETTURE DI LUCIA MAGGIA Nity

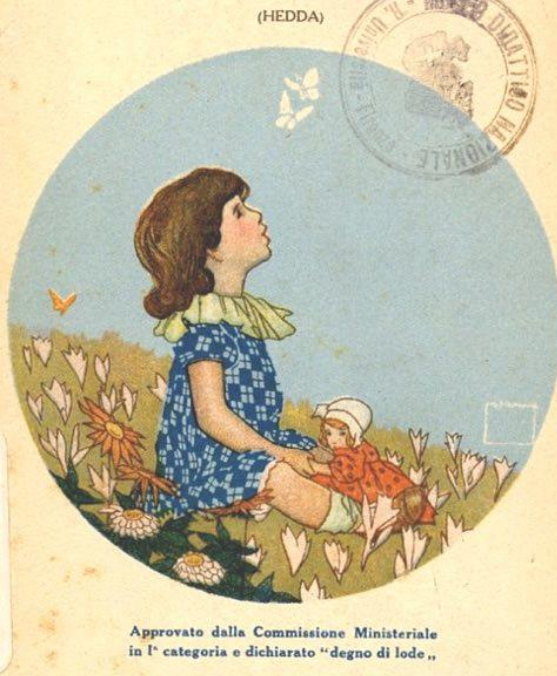

A. MONDADORI - MILANO
Image n. 4

V. Brocchi, A. Gustarelli, L'alba, la storia di Allegretto e Serenella, Milano, Mondadori, 1921. Illustrator Pinochi.

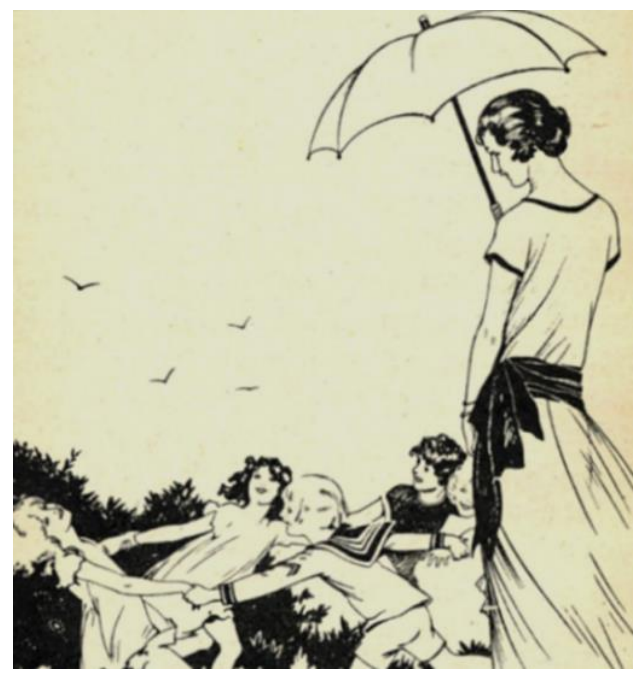

Image n. 5

V. Brocchi, A. Gustarelli, Allegretto e Serenella: corso di letture scolastiche - classe seconda, Milano, Mondadori, 1924, Illustrator Cambellotti.

Image n. 6

Lucia Maggia, Serenità, Milano, Mondadori, 1923, Illustrator Pinochi. 
With the following Commissions $(1925,1926,1927,1928)$ the first process of 'fascistization' began. But it failed: the Ministerial Report of the 1927 Commission stated: "The school book must be deeply pedagogical and must fit perfectly the historical moment [...]. Hence it needs to inspire passion for heroism and for all the typically manly virtues such as loyalty, courage, work, persevering, unselfishness, honesty, as well as the cult of our fathers' religion and the respect for authority and hierarchy, without forgetting [...] generosity and being good hearted: feelings and virtues that, awakened and cultivated since childhood and adolescence contribute to really form that way of life and that new man, that the Country is expecting from the reformed school. Now many school books, examined by the Commission, lack this Fascist spirit [...] this defect becomes evident for the forced and mechanic intrusion of pages which are false and rhetoric in a pitiful way" (Ascenzi and Sani, 2005, p. 666).

So while the government was carrying out this gradual fascistization of schools, also altering the Gentile Reform, the schoolbooks were still not sufficiently imbued with the Fascist spirit (Polenghi 2015). The two aforementioned books, for instance, along with many others, did not change much in their post 1923 editions. In Serenità, for example, a few pages dedicated to Mussolini were added in 1929 (Bacigalupi and Fossati, 1986, pp.174-177), whereas the text of Allegretto e Serenella was not altered at all. New schoolbooks, written after 1923, contained a clearer Fascist message.

\section{The Single school textbook (1930-44): the Fascist child}

The lack of Fascist spirit in the elementary school textbooks was patent: inserting a few pages on Mussolini or the heroic deeds of boys would not be enough. The "Fascist reclamation" of textbooks required new books (Sani, 2008). Hence, the Law of 7 January 1929 prescribed the introduction of the so-called Single school textbook [Testo unico di Stato] into elementary schools from 1930-31, videlicet the same book for every class and/or subject. According to the Minister Balbino Giuliano, a friend of Gentile, the inspiring criteria had to be: "1. to bring children into contact with real life; 2 . to give children the feeling of this marvellous new meaning of being Italian, thanks to Fascism; 3. to provide a Fascist education which is not ephemeral rhetoric, but which arises naturally from young souls in contact with real life" (Bacigalupi and Fossati, 1986, p. 191).

In these criteria one can see the attempt to preserve Lombardo Radice's recommendation to write schoolbooks that were close to real life, with images of real children, but imbued with Fascist values. The previous books were too refined, too psychological, too observant of individual differences. Important authors such as Grazia Deledda and Angiolo Novaro and accomplished illustrators such as Pinochi, Cambellotti and Angoletta collaborated on the creation of these new books, but in the Commission there were also politicians.

Our analysis will concentrate on some of these books (being compulsory, they were printed in hundreds of thousand copies) to detect in the texts as well as in their imagery how this pedagogy of the new Fascist child was delivered. The visual pedagogy (see at least Dussel and Priem, 2017) was carefully implemented by the regime propaganda through newspapers, magazines, movies, newsreels, posters, and postcards (Malvano, 1988). The iconic message 
is therefore significant as well, since it was immediate, simple and (often) captivating, and therefore could have a strong impact, especially on children (Gabrielli and Montino, 2009, p. 163-169).

In the Primer for the first class of 1930 (Dina Bucciarelli Belardinelli, Sillabario e piccole letture, Palermo, Poligrafico dello Stato, ed. 1932), the first pages presented the vowels and a child dressed as a Balilla writing "Eia" on a blackboard (image n. 7). This became a cliché we find in all books, with children shouting the Fascist motto coined by D'Annunzio: "Eia, eia, alalà" (Image n. 8). There were photos of il Duce, of the Pope and of the King and Queen. All the other images were drawings. Short religious texts on Jesus (image n. 9), Mary, and guardian angels were interwoven with short texts on Mussolini and patriotism. Traditional themes, such as cleanliness, love, animals, nature, and the loving mother were there, so that the text combined Fascism, the Catholic faith (fully reinstated in schools after Gentile's school reform of 1923 and Lateran Pacts in 1929) and traditional values and topics for children.

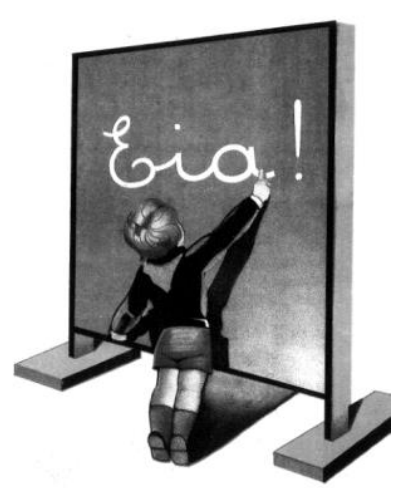

Image n. 7

D. Bucciarelli Belardinelli, Sillabario e piccole letture, 1930 , p. 7.

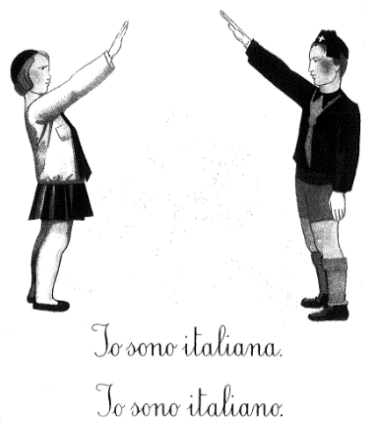

Per l'Italia nostra: eia, eia, eia, alalà!

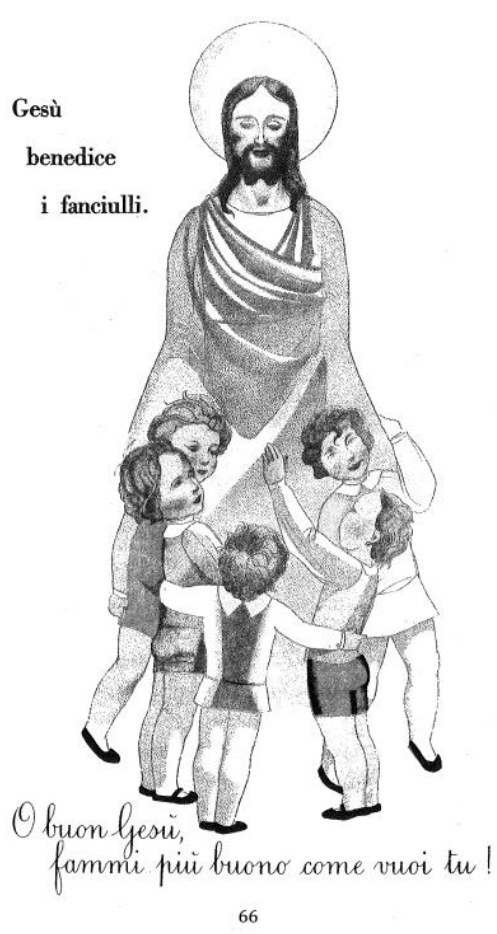

Image n. 9

D. Bucciarelli Belardinelli, Sillabario e piccole letture, 1930, p. 66.

Image n. 8

D. Bucciarelli Belardinelli, Sillabario

e piccole letture, 1930, p. 30. 
In the new Reader for the first class of 1936 (Libro della prima classe, Verona, Mondadori, 1936) we find many pleasant images of joyful children, not very different from the previous books (Image n. 10 - compare with Images n. 5), along with images of the aeroplane (a stereotypical picture, symbolizing dominion over the air, associated with the eagle, the queen of the sky and with Mussolini as an aviator, that is to be found in every schoolbook) (Ricuperati, 1975), and images of Mussolini, Balilla and soldiers (image n. 11). The texts are simple, without difficult words. The topics are still the traditional ones: cleanliness; patriotism; devotion to the Monarchy and il Duce; love of the family (with the mother always caring and working at home until late in the night); and the values of honesty and loyalty. The draining of the Agro Pontino and the foundation of the town of Littoria (now Latina) is presented as a fairy tale, and il Duce a kind of wizard who managed an impossible undertaking. All children aspire to become soldiers, aviators or sailors.

The general tone is mild and sweet, there are no excesses, the atmosphere is serene and the images are pleasant. Fascism is presented as natural, joyful and non-violent, a sort of "tamed" dictatorship, suitable for small children. Mussolini, along with the monarchy, is represented in photos that children could easily recognize. He is depicted as a loving father of all little Italians. The "Eia, eia alalà" shout features on many pages. Catholic and political messages are often put on facing pages (Image n. 12): for instance, the left page is about Easter and the Resurrection while the right-hand page shows a boy (with the Latin name Quirino) buying an exercise book and choosing the one with Mussolini's photo on the cover - one of the cross references between notebooks and textbooks (image n. 13).

Heroic deeds are also featured: the courage of a peasant boy who saves a girl from drowning is the theme of the last short story.

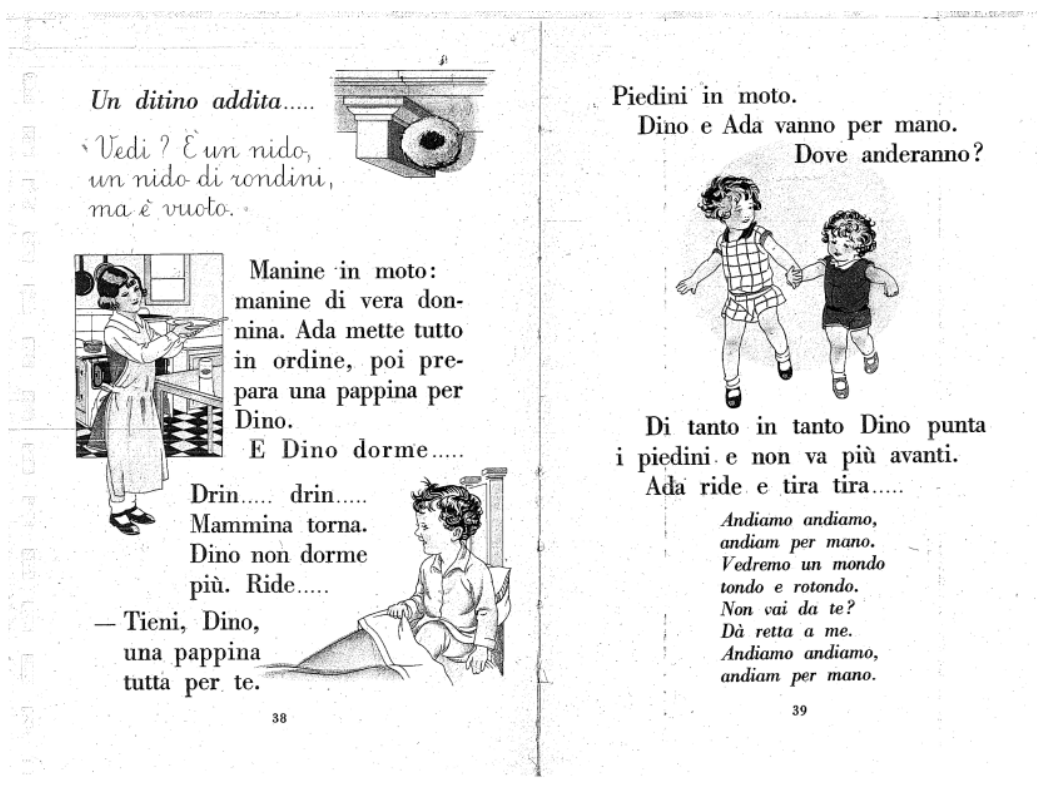

Image n. 10

Libro della prima classe, pp. 38-39. 


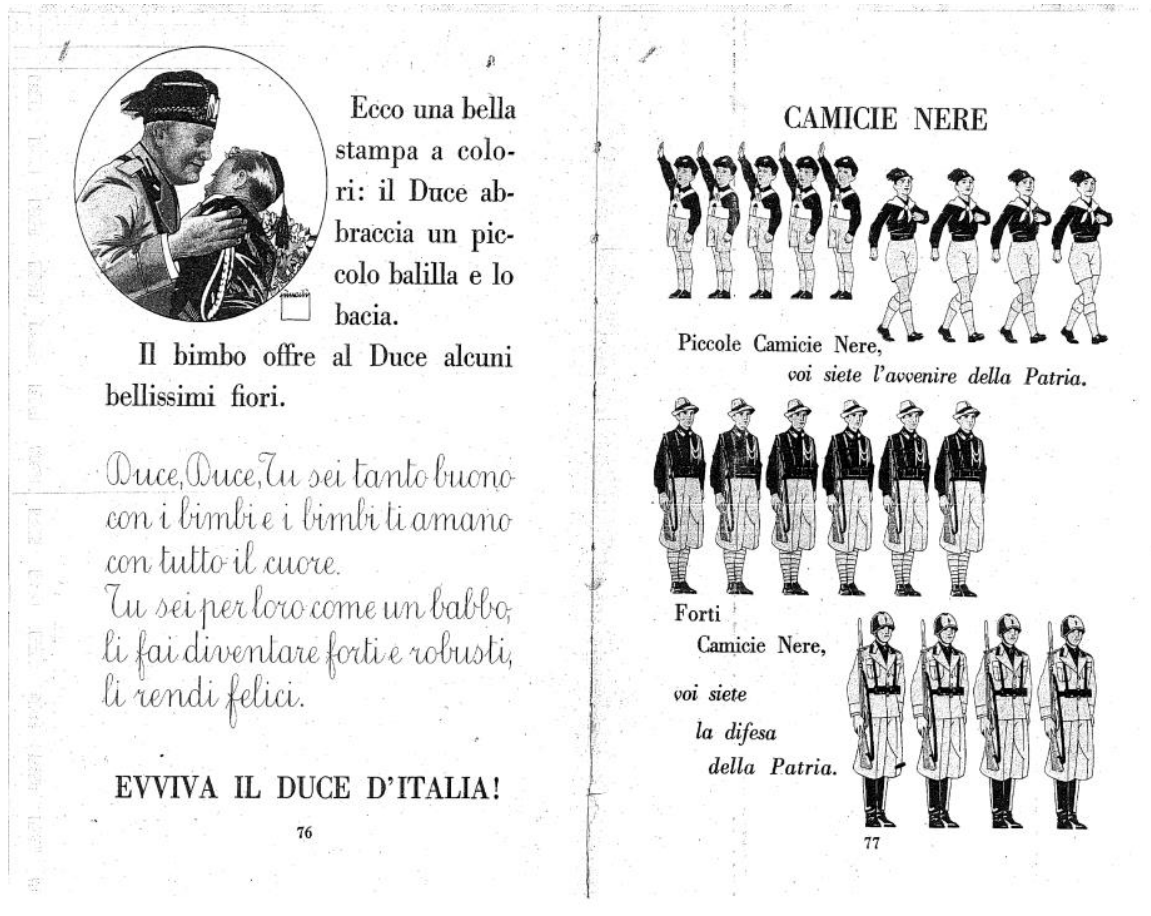

Image n. 11

Libro della prima classe, pp. 76-77.

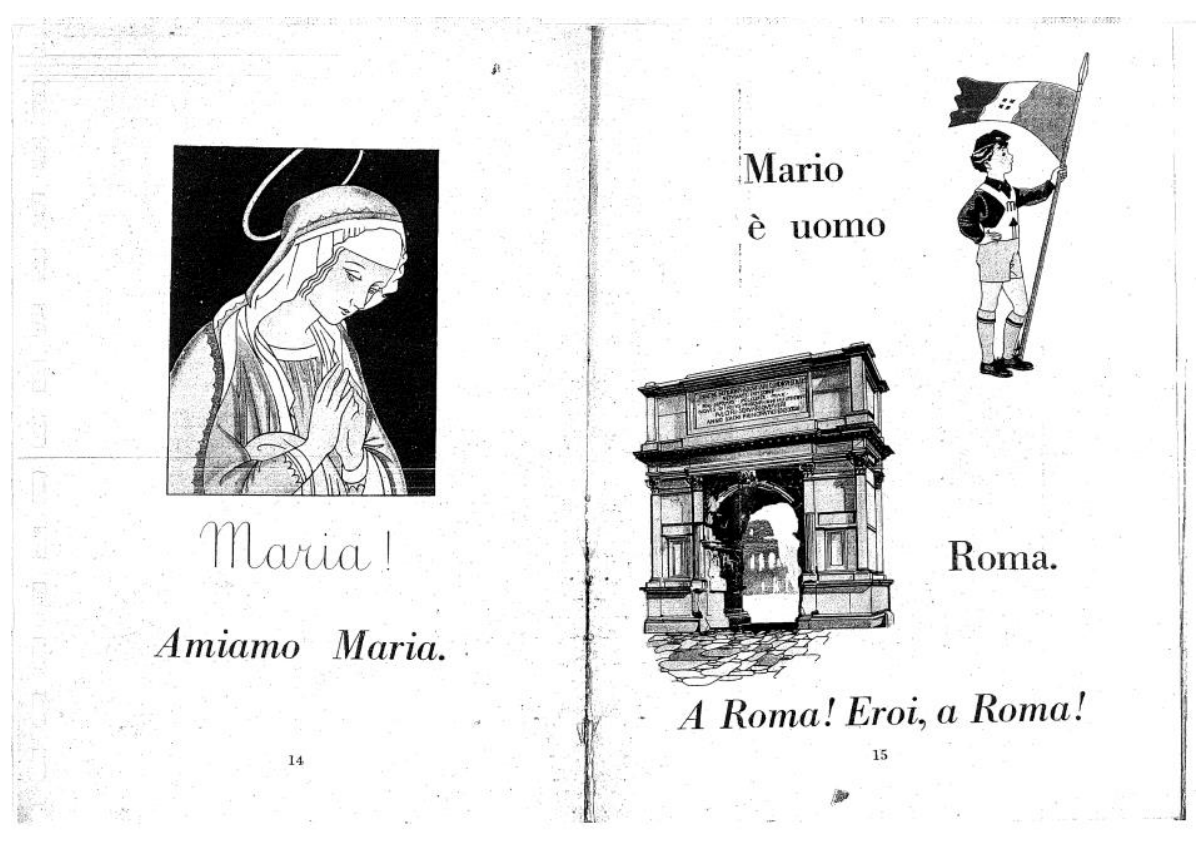

Image n. 12

Libro della prima classe, pp. 14-15. 


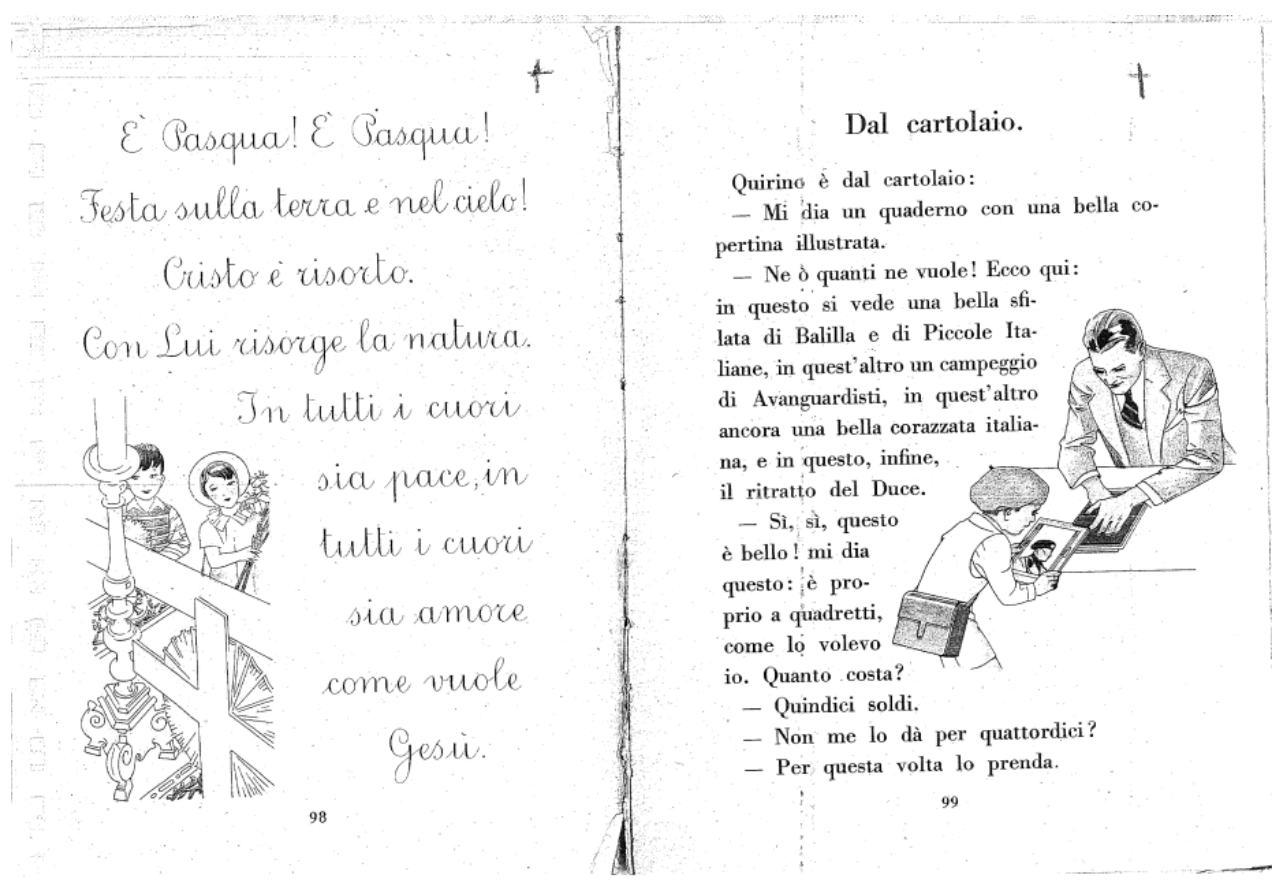

Image n. 13

Libro della prima classe, pp. 98-99.

The Reading book for the second class was written by Ornella, the nickname of Oronzina Quercia Tanzarella, author of a book judged favourably by Lombardo Radice's Commission, who in 1927 published Giovinezza [Youth], a reading book with a decidedly Fascist stamp (Bacigalupi and Fossati, 1986, pp. 181-187). Ornella's reading book was finely illustrated by Mario Pompei (O. Quercia Tanzarella (Ornella), Il libro della seconda classe. Letture, Firenze, Vallecchi, 1930). Fascism features heavily in the book, which shows children eager to become Balilla and prove their value, but it also presents Catholic subjects, such as Christmas and Easter. The images are pretty, with some pages in colour (image n. 14). Pompei was a skilled stage designer and illustrator, who was inspired by Art Nouveau. He illustrated many children's journals and books, among them Pinocchio, so that many pupils would probably recognize his style. The children's faces were round and the colourful drawings resembled those in comics. The young Balilla were cheerful and even when the message of militarization was evident, the graphic treatment of it was so appealing that it managed to disguise any violence within a joyful and childish image - see for instance the final page with the small happy Balilla grasping a pen, while his big and menacing shadow is that of a soldier grasping a bayonet. The shadow is squared, while the Balilla is round like a puppet (image n. 15). On one well-known page, a wise man, who wears a long beard like a wizard, tells the little Balilla that the first, second and third virtue of a child is obedience. The forcefulness of the message is mitigated by the drawing, which resembles a picture from a children's book (image n. 16). 


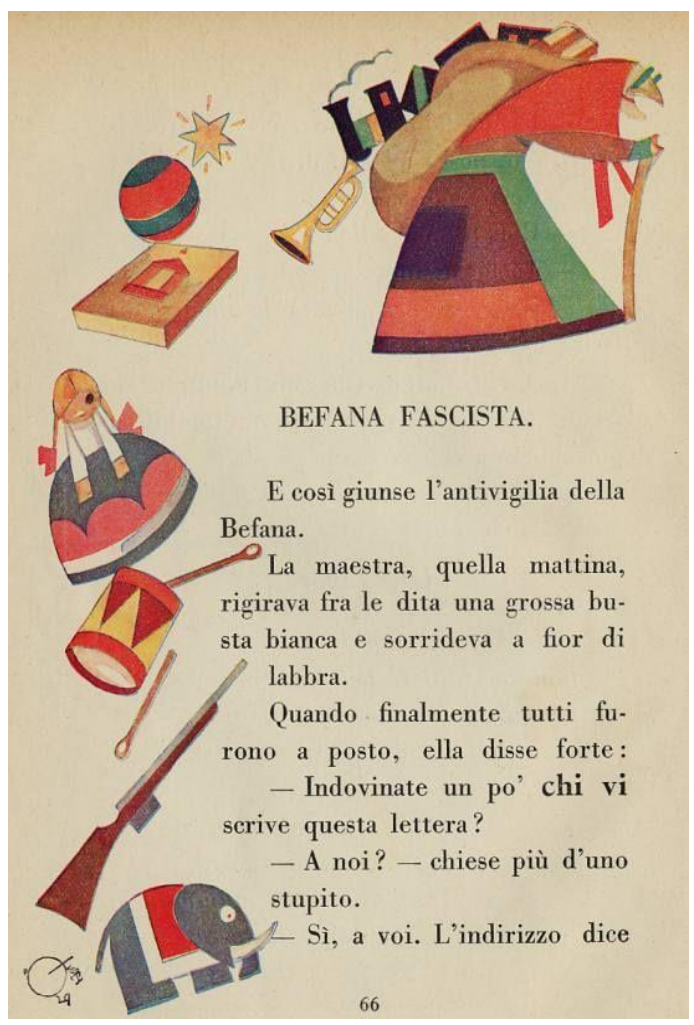

Image n. 14

Ornella, Il libro della seconda classe, 1930, p. 66.

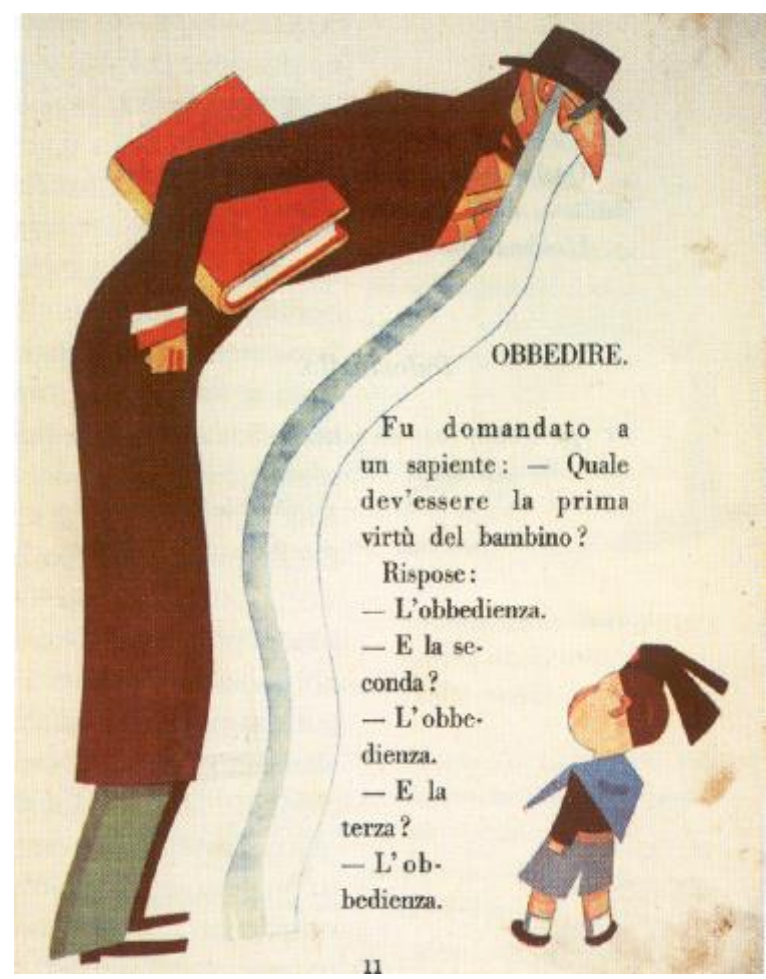

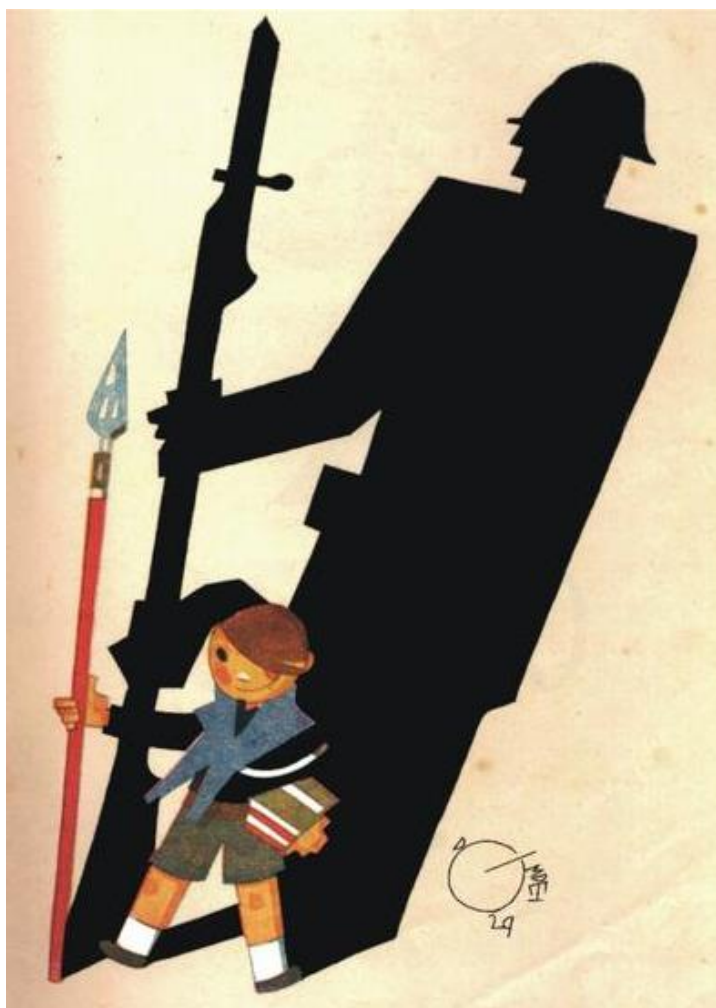

Image n. 15

Ornella, Il libro della seconda classe, 1930, p. 143.
Image n. 16

Ornella, Il libro della seconda classe, 1930, p. 11. 
The same can be said, for instance, of the short story about a lying black boy, described as a stupid "savage", whose lies are easily uncovered by a missionary. The text is racist, but the colonial conquest contains no violence, since it is represented as being among the Church's good deeds and the picture, again, could have been in a children's book or magazine (image n. 17). Similarly, the images of the Balillas marching or saluting in greeting, in spite of the sameness of the boys, and therefore the indication of them as a "mass-child" [bambino-massa], give the idea of children playing, smiling happily, rather than being little military soldiers (images n. 18-19.).

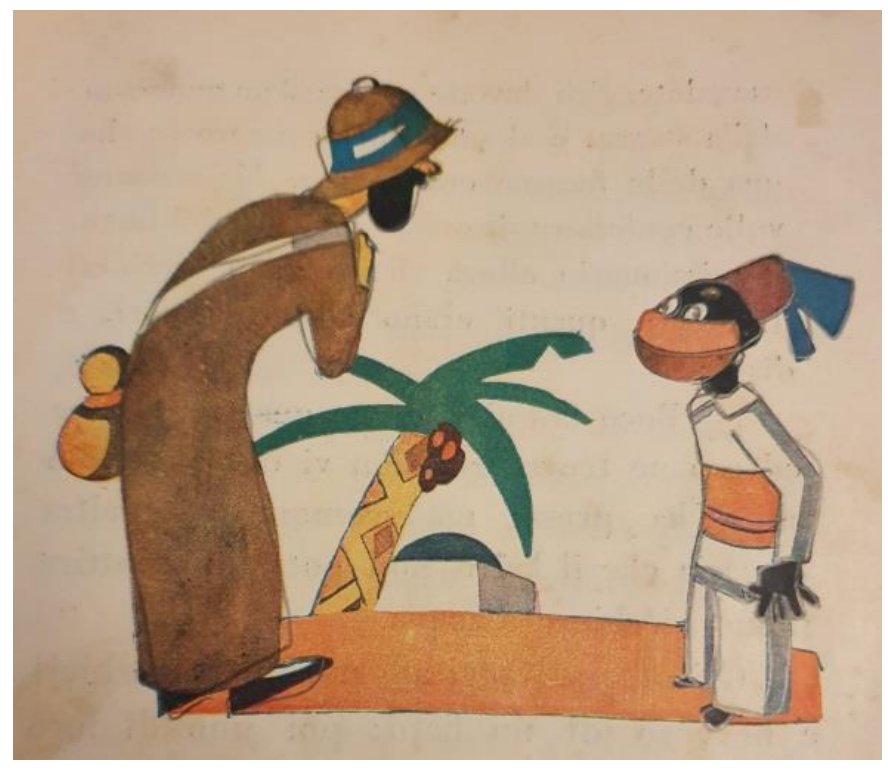

Image n. 17

Ornella, Il libro della seconda classe, 1930, p. 117.

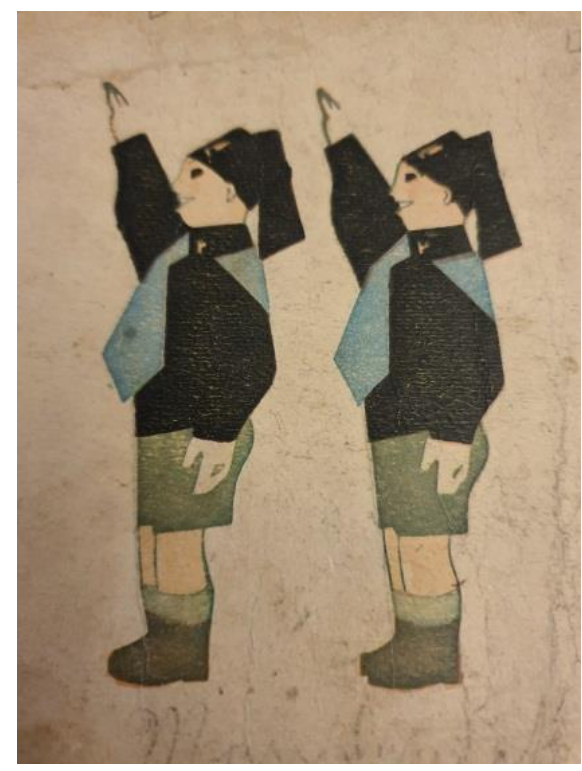

Image n. 18

Ornella, Il libro della seconda classe, 1930 , cover.

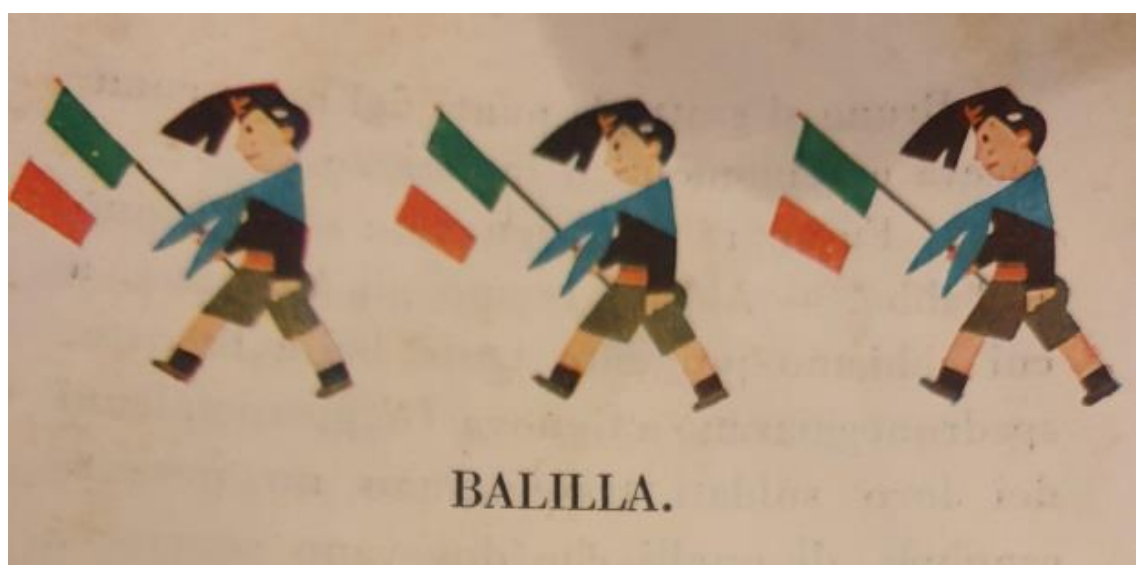

Image n. 19

Ornella, Il libro della seconda classe, 1930, p. 113. 
As in the book for the first class, the only photos in this book were those of il Duce, the Pope and the Royal Family, as if the pupils had to recognize clearly the highest authorities, who also had to be graphically different from the childish world depicted.

In 1936 Ornella's Reading book for the second class was replaced by one by Alfredo Petrucci, which bore a much more obvious Fascist stamp. It had the emblematic subtitle: "The new Italian". The epigraph was this statement by il Duce: "You must begin to live according to the style of the very new man. What is this style? First of all work, then discipline, unselfishness, an honest life, loyalty, sincerity, courage." In the book you see the serene and prolific family of a peasant: the old parents have children, one is war-disabled (blind), while three of them already have many children of their own. Italy, as in the other books, is always defined as beautiful, for its nature and its artistic heritage. Italy is described as powerful and feared, children are proud to be Italians, and the heirs of ancient Rome. "The new Italian" is a soldier from birth, who serves his country all his life, so as to see Italy bigger, more powerful, and more feared every day. Sport and exercise are important to the new child, to become stronger and healthier. Ethiopia is mentioned, and Mussolini is depicted as a modern hero and superior man, who has the power to make a little deaf-mute pronounce the word Duce, while in the adoring crowd listening to Mussolini in Piazza Venezia. Most of the book's pages are an exaltation of Mussolini and the Fascist State. The monarchy and the element of the Catholic faith are present, too. The book ends with a quote about the new Italian, who is ready to serve Italy "and does not stop, he keeps marching on with his iron will, ready to win every day" (Alfredo Petrucci, L'italiano nuovo, Letture della $2^{\circ}$ classe elementare, Verona, Mondadori, 1940, p. 191). The images in this book are far removed from Pompei's refined style, but are much more stylized, and resemble the typical Fascist style of posters and visual propaganda (images n. 20-21).

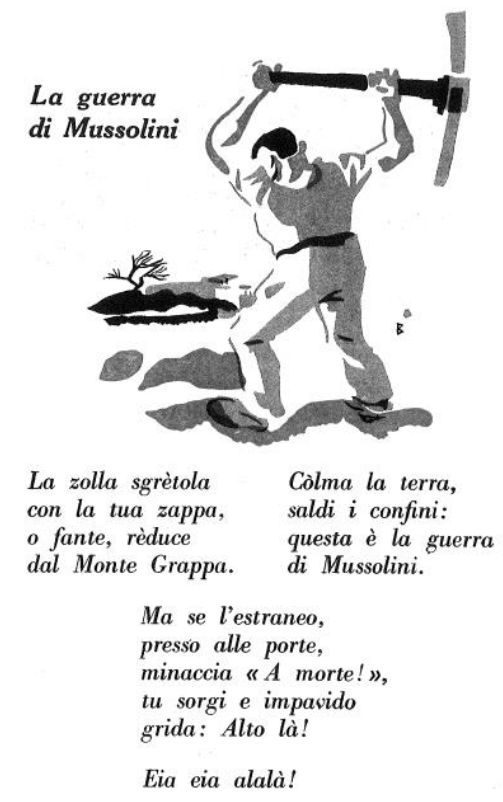

Image n. 20

Petrucci, L'italiano nuovo, p. 59.

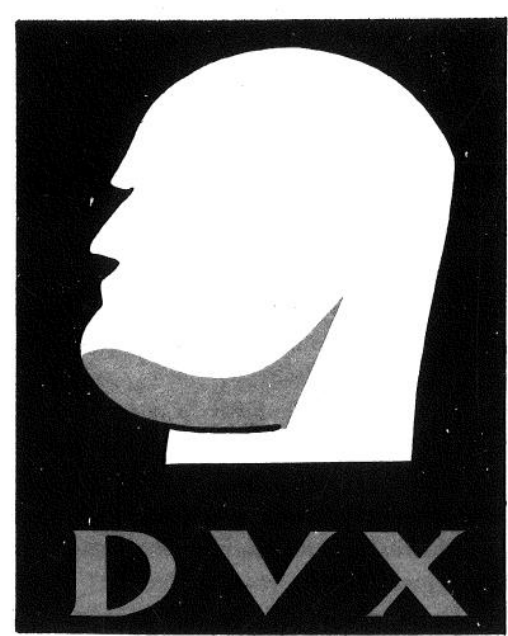

le orbite profonde poi, il naso, la bocca, il mento robusto. Pareva che volesse imprimersene ogni particolare nei polpastrelli e rimodellarlo nella sua memoria. Infine tenne la

Image n. 21

Petrucci, L'italiano nuovo, p. 158. 
The Reading books for the $3^{\text {rd }}, 4^{\text {th }}$, and $5^{\text {th }}$ classes were structured as novels with a child and his family and/or his classmates as main characters, following the successful models of Cuore (Hearth), but also of previous school textbooks such as Giannetto (Little John) (1837), which had echoes of Pestalozzi's Lienhard und Gertrud.

The book for the third class was written by Grazia Deledda, a very famous writer who was awarded the Nobel Prize for literature in 1926 (Grazia Deledda, Il libro della terza classe elementare, letture. Roma, Libreria dello Stato, 1930). In spite of the author's fame, this book was the one that suffered most criticism and became the first to be replaced. Deledda's book inserted various short stories and texts into the overall framework of the story of a group of school mates, hence resembling Cuore. Cuore, though, was cruder and more realistic, whereas the tone here was lighter. There was no reference to the family. The simplicity of the book's structure contrasted with the difficulty of the language.

Here, as in Cuore, we find the archetypes of the nasty boy and the good-hearted disabled child. Cherubino is the nasty boy, who is ignorant, ugly, a liar, dirty, and who has already failed at school the year before; Anselmo, lame in one leg, is very handsome, clever, cheerful, and the most diligent. In this work however, the figure of the nasty boy is presented with a difference: Cherubino is described differently to Cuore's famous Franti: "It is not all his fault: partly it's due to nature, which made him ugly and malicious, partly it is due to the life he has. [...] His parents are well-off, but having to spend all day in their shop, they do not look after him. [...] So, he plays with bad boys in the streets" (Deledda, Il libro della terza classe elementare, pp. 7-8). His father hits him, even when he has done nothing wrong. In the end, unlike Franti, who is expelled, Cherubino will move up to the $4^{\circ}$ form. The idea of an irredeemable child was unacceptable to the educational theories of Lombardo Radice, to the Progressive pedagogy and to Deledda.

The main character in the story is Sergio. His father takes him to Predappio, to visit il Duce's birthplace. He tells him about the history of Italy, about the sacrifice of a lame boy who helped the Italian soldiers; about Balilla, Garibaldi, WWI. Italians are described as "the most heroic people in the world". Sergio's world is a rural Italy. Religion features in it but not too heavily. There is a short chapter on the Lateran Treaty. It strikes a patriotic tone, but there is a clear undertone of Fascist ideology. As in Cuore, Deledda stresses virtues, good and bad deeds and their consequences. Similarly, there is a message of equality: "in a school class there are neither rich nor poor; they are all equal and brothers and only the best is the real signore [lord]" (Ibidem, p. 8).

The final message is: Life is difficult, we have to work hard. Do not envy richer children. "It is enough to see a tree, a flower, a star and be near your mother to be happy" (Ibidem, p. 151). The images, by Pio Pullini, are less numerous than in the books for the first two classes and they call to mind traditional children's books (images n. 22-23). The pictures also contain a clear undertone of the concept of Fascism. The pages on history are fully aligned with Fascism, but the reading section is much less strident. 


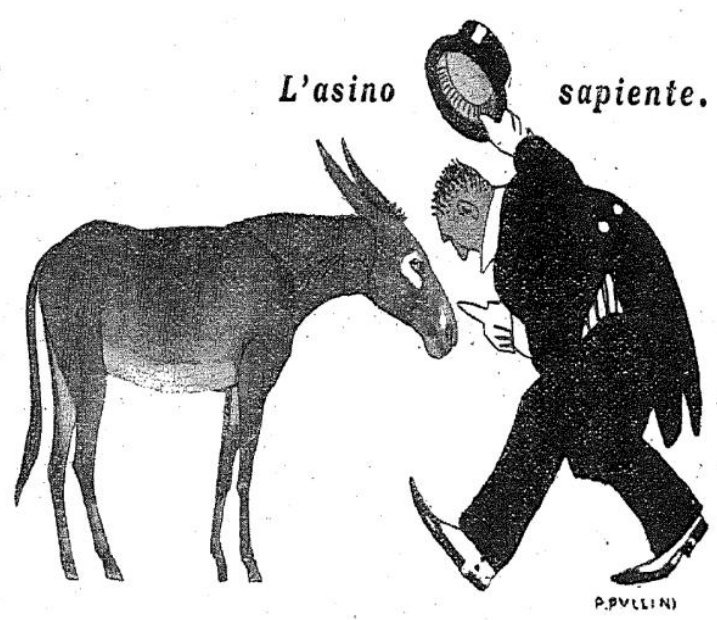

Image n. 22

Deledda, Il libro della terza classe elementare, p. 49.

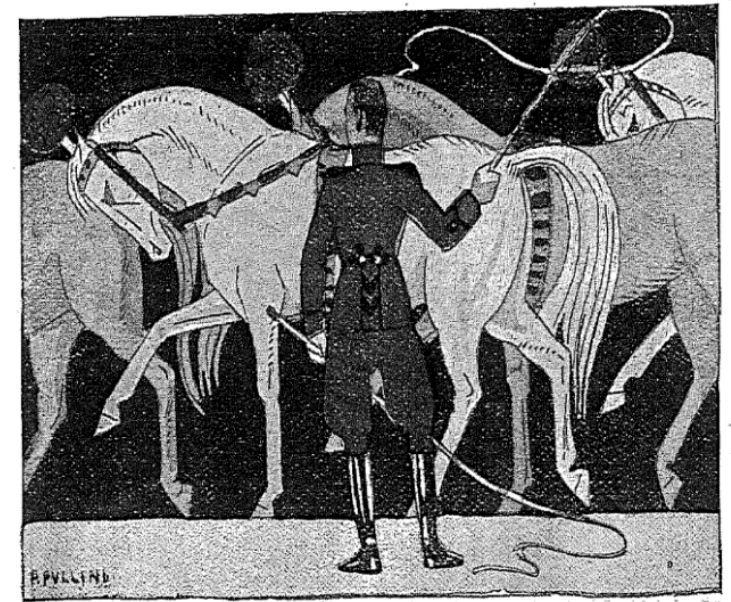

Image n. 23

Deledda, Il libro della terza classe elementare, p. 44.

It is unsurprising then that in 1935 Deledda's Reading book for the $3^{\circ}$ class was replaced by a heavily Fascist one by Nazzareno Padellaro (N. Padellaro, Il Libro della terza classe elementare. Letture, Roma, Libreria dello Stato, 1935). Padellaro was a high-ranking school officer, the author of many school textbooks. Catholic and conservative, he adhered to Fascism with conviction, regarding the State propaganda and the Fascist ideology as the only true means of educating children. He opposed Lombardo Radice's theory of education, progressive education, Montessori and Dewey. He managed to survive the anti-Fascist purges in Republican Italy and was the Minister of Education's chief director (Meda, 2013).

In Padellaro's Reading book the Fascist State is described as a supreme religious entity. Padellaro uses short sentences or slogans that resemble a Futuristic style, far removed from a language suited to children, but close to Mussolini's speeches (Bacigalupi and Fossati, 1986, pp. 219-221). The violent language of early Fascism is also widely used: there are knives, bludgeons and hand-grenades in these pages. The Roman empire is glorified and seen as the ancestor of the Fascist State. From 1936, episodes from the Second Ethiopian war as well as from WWI are included in the book. It is filled with heroic military deeds, which render it quite unbearable und unrealistic. The images are those of a "mass-child", all stereotyped and equal Balillas. The faces are often not visible, to emphasize the effect of massification, or else resemble statues in their fixity (images n. 24-25). 


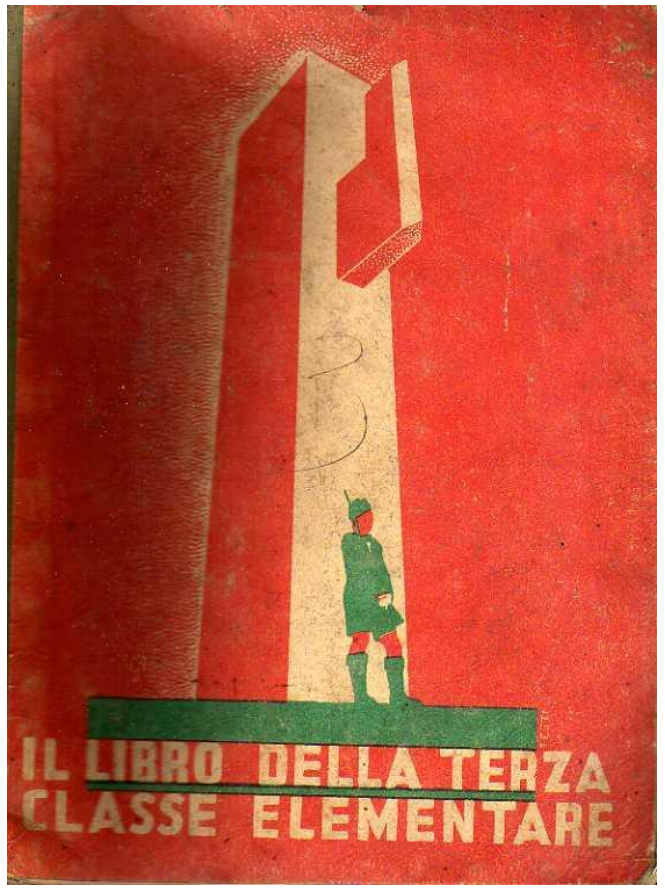

Image n. 24

N. Padellaro, Il Libro della terza classe elementare 1935 , p. 3.

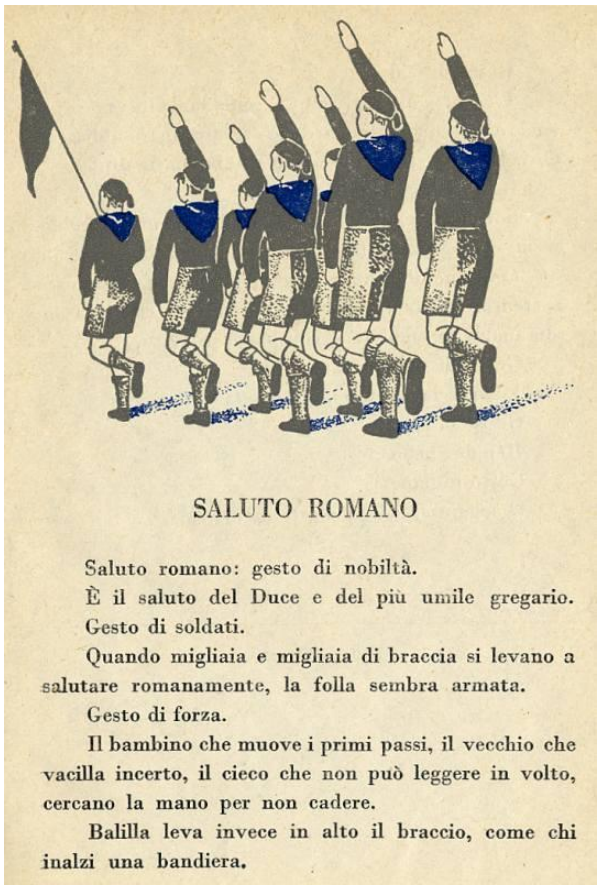

Image n. 25

N. Padellaro, Il Libro della terza classe elementare 1935, cover.

The Reading book for the fourth class was written by Angiolo Silvio Novaro, a rather famous poet and writer (A. S. Novaro, Il libro della IV classe, letture, Roma, Libreria dello Stato, 1930). It was revised in 1935. The narrative of the child's family becomes just one of the short stories, much space being given to the heroic deeds of Balillas, which are seen as the effect of a Fascist education, videlicet of a physical as well as moral education: love for Italy and affection for friends, a sense of duty, courage, discipline, pride in being Italian are the relevant values. There is a character who is war-disabled, but his amputation is minor (having lost two fingers). Fascism is presented as a movement of young people and Mussolini's life as a model. Life in the countryside is good - a message we find in many schoolbooks. As in the third class reader, the section dedicated to history is full of stories of Italian martyrs in WWI and of Fascists killed by Communists in the aftermath. In this book there are only a few illustrations and no images of children.

The Reader for the fifth class, Il Balilla Vittorio, is considered the best of all the Single school textbooks. It is this book that is closest to the model book Fascism was looking for. The author, Roberto Forges Davanzati, was a journalist, ex-socialist and a war hero, a Fascist who held a high position in the Party, and who was president of the Society of Italian writers and publishing houses, the director of radio propaganda, and a member of the Senate since 1934. The books tells the story of a boy and his family (of eight brothers and sisters). The father is transferred to Rome. This allows Forges Davanzati to dedicate many pages to the capital, 
illustrating its beauty. Rome is the city of the Roman Empire, of the Church, of the new Fascist State, that is the heir to the ancient state of Rome and that is at peace with the Church of the Pope.

The model, once again, is Cuore. Hence, there are letters from relatives, an expedient that allows the author to show other cities and situations. Vittorio goes on journeys, enabling the author to describe other cities and landscapes, always drawing attention to the greatness of Fascist works and modernizations: the draining of the Agro Pontino marsh, new railway stations, the navy, Albania and Rhodes. The virtues of the good Italian are narrated or shown with exempla by members of the family or other characters. The good Fascist boy is brave but also clever and reflective, ready to act, but not in a blind way, (R. Forges Davanzati. Il libro della quinta classe. Il Balilla Vittorio. Racconto, Roma, Poligrafico dello Stato, pp. 94-95). Vittorio lives in a Fascist Italy, so there is no need to stress ideology. The situations are natural and realistic, the participation in and support for Fascism is taken for granted, so the tone is not exaggerated. WWI plays a central role, without any particular rhetoric, but as a key recent event that has affected every family (Juhász, 2009, pp. 245-248). The patriotic message sounds sincere. When in the end Vittorio's family return to their little town, they are happier. Vittorio will study in a school for agriculture: again a message in favour of rural Italy. The images are all photographs, which helps to maintain the realistic tone. As well as pictures of towns, of Rome, and of animals, there are pictures of pupils and of the Grazioli school in Rome, as if Vittorio were a real boy in the capital (images 26-27). The photos of Mussolini show il Duce alongside boys, presenting them with awards, greeting them, giving them gifts (images 28-29). In 1936 the appendix was changed to focus on the Second Ethiopian war. Mussolini's power comes from the people, since he personifies the will of the people. He is a popular hero, like Garibaldi.

Vittorio is a real child, with real emotions and feelings. His family occupies a central place in the book. People believe in Fascist values, which are patriotic but not racist. Forges Davanzati succeeds in merging Lombardo Radice's model with that recommended by Balbino Giuliano in 1929.

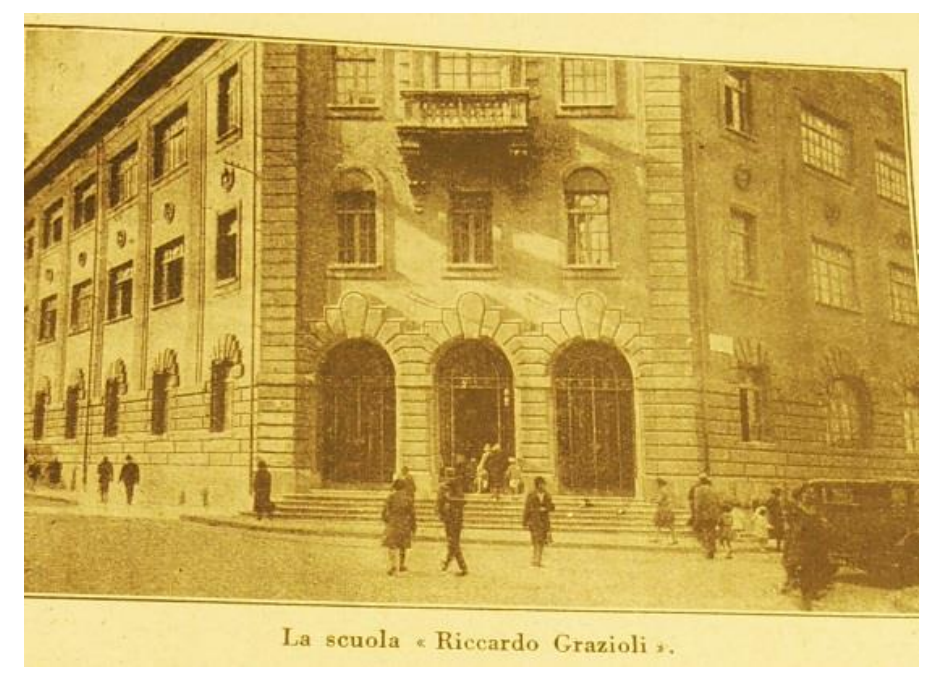

Image n. 26

R. Forges Davanzati. Il Balilla Vittorio, p. 65. 


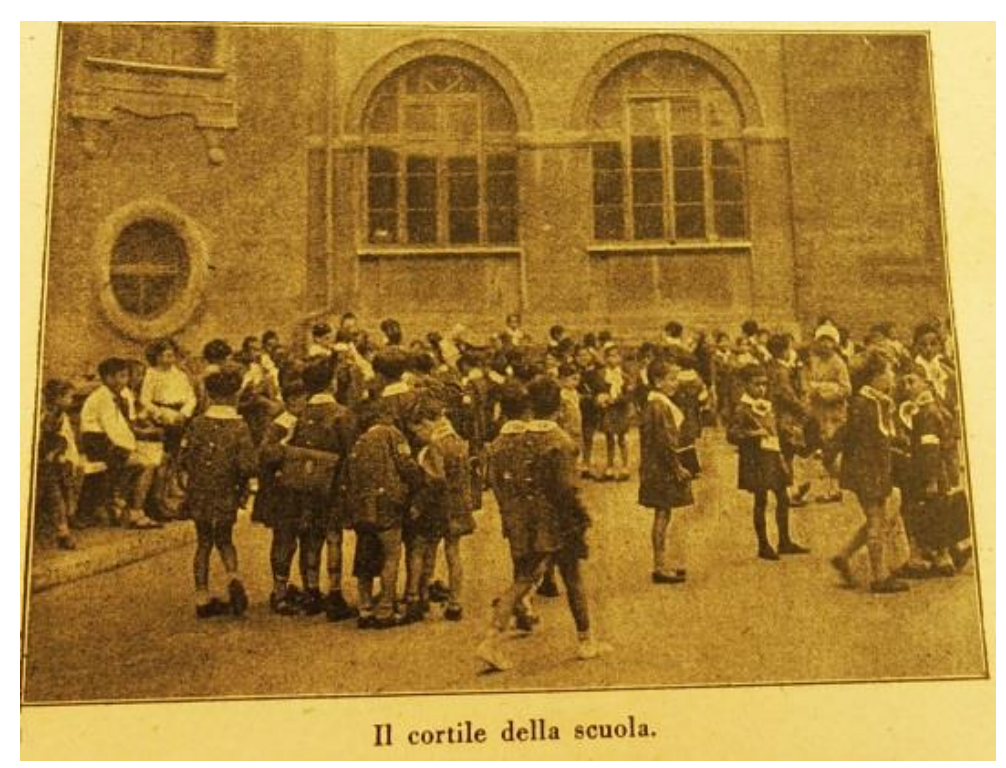

Image n. 27

R. Forges Davanzati. Il Balilla Vittorio, p. 65.

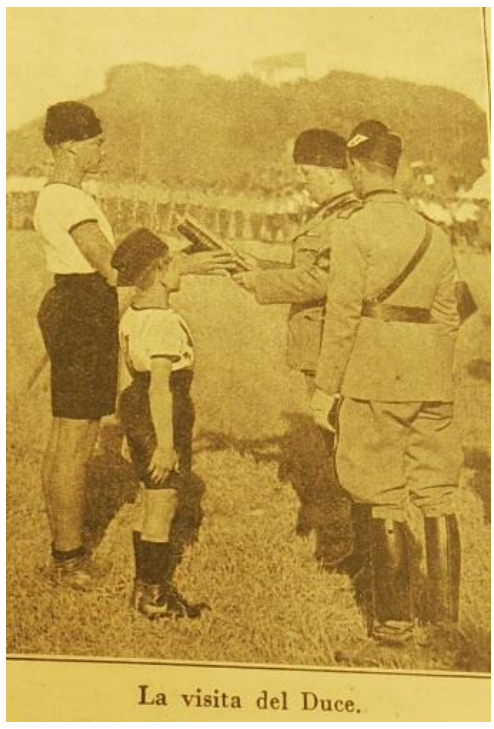

Image n. 28

R. Forges Davanzati. Il Balilla Vittorio, p. 224.

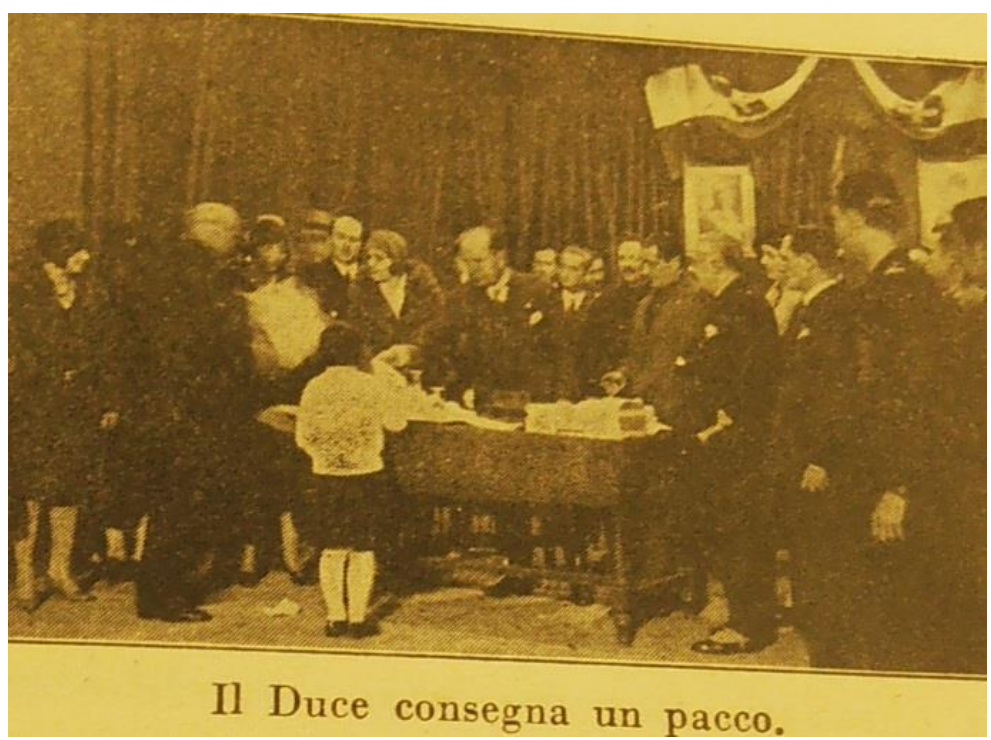

Image n. 29

R. Forges Davanzati. Il Balilla Vittorio, p. 153.

If in the mid thirties, with the Second Ethiopian war, the school textbooks tend towards militarization, this change becomes total with WWII: between 1939 and 1941 all Single State school books were changed. The militaristic tone is exaggerated, even if there is no reference to the ongoing war: WWI especially, but also the Ethiopian war, and even the Spanish civil war are hammered home, so that whilst the primer and the reading books for the first two classes still leave space for the description of children and the family, the reading books for the upper three classes become an anthology of war episodes (Bacigalupi and Fossati, 1986, 
pp. 218-23). As mentioned previously, this change is coherent with the Exercise book covers devoted to the "Heroic youth" deployed on the war fronts, that appeared in the mid-1930s (Ascenzi and Sani, 2018).

\section{Conclusions}

The Single textbook was used without enthusiasm. Teachers were critical of it (according to the 1934 Inquiry). Some authors, like Grazia Deledda, deployed a vocabulary that was too complex, and the teachers confessed that they had to use alternative readings, which were more captivating, such as Pinocchio or children's magazines. As late as 1937 teachers were still using other texts alongside the prescribed Single school textbooks. (Bacigalupi and Fossati, 1986, pp. 191-198).

The search for truly Fascist schoolbooks was a never-ending task. But if we remember the initial scheme of the four periods in the ideology of the new man, we can understand why: Fascism was not a static ideology and some traits changed or became more important over time. In all books Mussolini represented the new man, but the accentuation of the "mass-man" contrasted sharply with Lombardo Radice's model, which managed to survive buried within the texts or in the images.

After 1923, few pages about Mussolini and Balilla were added, but il Duce as the new man featured constantly in the textbooks of the following years. The symbol of the eagle and the aviator were always used so the first model, according to Pazzaglia's analysis, was ever present in schoolbooks. Indeed it provided a simple and clear model of a real man to be imitated.

An examination of the texts and images in various State textbooks, however, reveals a complex mixture of traditional educational messages, centred around the Catholic faith (which was fully reinstated in schools after Gentile's School reform in 1923 and the Lateran Pacts in 1929), patriotic values and il Duce's exaltation. It has been noted that the "new man" was initially an anti-liberal man and then a "mass-man", with no personal identity. The messages we find in State textbooks also reveal themes which were sometimes contradictory, particularly in the last phase (Christian peace and Fascist war, for example). The importance of the family, which was constantly underlined, undermined the "mass-man" messages. Traditional rural values coexisted with the spirit of modernization. There were only faint signs of modernization seen in women's educational models, which remained very traditional (emphasizing the good wife and mother).

The pre-Fascist topics of cleanliness, motherhood, and gender education persisted; as did the literary models (Cuore), and the moral values of solidarity, obedience, loyalty, and willing pupils. The Single textbook halted the pedagogical revolution led by Lombardo Radice and killed off the new books, replacing the notion of the Neo-Idealistic - progressive child with that of the totalitarian child. However, some traits of that pedagogical revolution managed to survive, especially in the books for the youngest pupils, for whom a joyful style was perceived as more appropriate, or in Il Balilla Vittorio (Sani, 2008, pp. 323-324). Somehow, paradoxically, the best books were those which did not forget the lessons of Lombardo 
Radice. The goal of educating the "new Fascist child" was differently achieved (or not) - see the above mentioned teachers complaints. Some messages were adapted to a child's mind, others were not, with the result that the former were probably more persuasive. The images for the youngest pupils took the form of drawings, which were often delicate in style and cheerful in tone. Significantly, the Monarchy, il Duce and the Pope were always portrayed with photos, as if a drawing could diminish their authority. In the schoolbooks for older children we find photos and a prevalence of militaristic themes.

The child in the books approved by Lombardo Radice is a happy middle-class child, who is good but can be naughty, can have problems, but lives a happy city life. The new child in Fascist books is a peasant child, who lives in rural areas, knows that life is hard, but copes with an intrepid heart, like a little soldier (or an ancient Roman). The New man, as E. Gentile has shown, was also a Roman legionary, and a good peasant. The anti-middle-class tone of early and late Fascism is also discernible in the Single school textbook.

The books approved by Lombardo Radice returned with the establishment of the Republic: Allegretto e Serenella and Serenità were reprinted in 1945 and subsequently (Rebellato, 2008, p. 28).

\section{Literature}

ASCENZI, Anna and SANI, Roberto, 2018. The totalitarian child: the image of childhood in the Fascist school notebooks (1922-1943). History of Education \& Children's Literature. Vol. 13, No. 1, pp. 251-278. ISSN 1971-1093 (print)/ISSN 1971-1131 (online).

ASCENZI, Anna and SANI, Roberto, ed., 2005. Il libro per la scuola tra idealismo e fascismo. L'opera della Commissione centrale per l'esame dei libri di testo da Giuseppe Lombardo Radice ad Alessandro Melchiori (1923-1928). Milano: Vita e Pensiero. ISBN 88343-1185-X.

ASCENZI, Anna and SANI, Roberto, ed., 2009. Il libro per la scuola nel ventennio fascista. La normativa sui libri di testo dalla Riforma Gentile alla fine della seconda Guerra mondiale. Macerata: Alfabetica. ISBN 978-88-902509-4-1.

BACIGALUPI, Marcella and FOSSATI, Piero, 1986. Da plebe a popolo. L'educazione popolare nei libri di scuola dall'Unita ala Repubblica. Firenze: La Nuova Italia. ISBN 88221-0289-4.

BARAUSSE, Alberto, ed., 2008. Il libro per la scuola dall'Unita al fascismo. La normativa sui libri di testo dalla legge Casati alla Riforma Gentile. Macerata: Alfabetica. ISBN 978-88902509-9-6.

BARIS, Tommaso, 2011. Il mito della giovinezza tra realtà e retorica nel regime fascista. In: DE NICOLÒ, Marco, ed. Dalla trincea alla piazza. L'irruzione dei giovani nel Novecento. Roma: Viella, pp. 185-204. ISBN 978-88-8334-416-9.

BETTI, Carmen, 1984. L'Opera nazionale balilla e l'educazione fascista. Firenze: La Nuova Italia. ISBN 88-221-0077-8. 
DUSSEL, Inés and PRIEM, Karin, 2017. The visual in histories of education: A Reappraisal. Paedagogica Historica. Vol. 53, No. 6, pp. 641-649. ISSN 0030-9230 (print)/ISSN 1477$674 \mathrm{X}$ (online).

FAVA, Sabrina, 2008. I libri di lettura e la Riforma Gentile. In: CHIOSSO, Giorgio, dir. Teseo Novecento. L'editoria per l'educazione e la scuola dal 1900 al 1943. Milano: Editrice Bibliografica, pp. 13-30. ISBN 978-88-7075-658-6.

GABRIELLI, Gianluca and MONTINO, Davide, 2009. La scuola fascista: istituzioni, parole d'ordine e luoghi dell'immaginario; introduced by Monica GALFRÉ. Verona: Ombre corte. ISBN 978-88-95366-43-2.

GALFRÉ, Monica, 2005. Il regime degli editori. Libri, scuola e fascismo. Roma-Bari: Laterza. ISBN 88-420-7796-8.

GENTILE, Emilio, 1990. Fascism as political religion. Journal of contemporary history. Vol. 25, No. 2/3, pp. 229-251. ISSN 0022-0094.

GENTILE, Emilio, 1993. Il culto del littorio: la sacralizzazione della politica nell'Italia fascista. Roma-Bari: Laterza. ISBN 88-420-4140-8.

GENTILE, Emilio, 2002. L" "uomo nuovo" del fascismo. Riflessioni su un esperimento totalitario di rivoluzione antropologica. In: Fascismo, storia e interpretazione. Roma-Bari: Laterza, pp. 235-264. ISBN 88-420-6771-7.

CHARNITZKY, Jurgen, 1994. Die Schulpolitik des faschistischen Regimes in Italien (19221943). Tübingen: Max Niemeyer Verlag. ISBN 3-484-82079-9.

CHIOSSO, Giorgio, 2006. Il rinnovamento del libro scolastico nelle esperienze di Giuseppe Lombardo Radice e dei «lombardiani». History of Education \& Children's Literature. Vol. 1, No. 1, pp. 127-139. ISSN 1971-1093 (print)/ISSN 1971-1131 (online).

CHIOSSO, Giorgio, 2013. Libri di scuola e mercato editoriale. Dal primo Ottocento alla Riforma Gentile. Milano: Franco Angeli. ISBN 978-88-204-2174-8.

JUHÁSZ, Balázs, 2009. La concezione storica del fascismo ne Il balilla Vittorio di Roberto Forges-Davanzati. ÖT KONTINENS, CINQ CONTINENTS, Les cahiers du Département d'Histoire moderne et contemporaine, pp. 235-265. ISSN 1589-3839.

LA ROVERE, Luca, 2002. "Rifare gli italiani": l'esperimento di creazione dell'"uomo nuovo" nel regime fascista. Annali di storia dell'educazione e delle istituzioni scolastiche. Vol. 9, pp. 51-77. ISSN 1723-9672.

MALVANO, Laura, 1988. Fascismo e politica dell'immagine. Torino: Bollati-Boringhieri. ISBN 88-339-0430-X.

MALVANO, Laura, 1994. Il mito della giovinezza attraverso l'immagine: il fascismo italiano. In: LEVI, Giovanni and SCHMITT, Jean-Claude, ed. Storia dei giovani. 2: L'età contemporanea. Roma-Bari: Laterza, pp. 311-348. ISBN 884204394X.

MEDA, Juri, 2013. Padellaro Nazareno. In CHIOSSO, Giorgio and SANI, Roberto, dir. Dizionario Biografico dell'Educazione (1800-2000). Milano: Editrice Bibliografica. Vol. 2, pp. 266-267. ISBN 9788870757279.

MONTINO, Davide, 2005. Le parole educate. Libri e quaderni fra fascismo e repubblica. Milano: Selena. ISBN 88-86267-95-9. 
MONTINO, Davide, 2007. Libro, quaderno e moschetto. Pedagogia della guerra nelle letture e scritture scolastiche durante il regime fascista. History of Education \& Children's Literature. Vol. 2, No. 2, pp. 193-216. ISSN 1971-1093 (print)/ISSN 1971-1131 (online).

MORANDINI, Maria Cristina, 2008. Fascismo e libro di Stato. Il caso dei sussidiari. In: CHIOSSO, Giorgio, dir. Teseo Novecento. L'editoria per l'educazione e la scuola dal 1900 al 1943. Milano: Editrice Bibliografica, pp. 55-74. ISBN 978-88-7075-658-6.

MORANDINI, Maria Cristina, 2019. I quaderni di epoca fascista veicolo di propaganda ideologica e strumento didattico: il fondo della scuola elementare Parini di Torino (19381942). Historia y Memoria de la Educación. No. 10, pp. 383-408. ISSN 2444-0043.

OLIVIERO, Stefano, 2007. L'editoria scolastica nel progetto egemonico dei neoidealisti. Pisa: ETS. ISBN 978-88-467-1800-6.

OSTENC, Michel, 1980. L'education en Italie pendant le fascisme. Paris: Publications de la Sorbonne. ISBN 2859440208.

PAZZAGLIA, Luciano, 2003. La Formazione dell'uomo nuovo nella strategia pedagogica del fascismo. In: PAZZAGLIA, Luciano, ed. Chiesa, cultura e educazione in Italia tra le due guerre. Brescia: La Scuola, pp. 105-146. ISBN 8835015308.

POLENGHI, Simonetta, 2015. Giovanni Gentiles Schulreform zwischen Liberalismus und Totalitarismus. Von der Revision der Schulbücher (1923) zum „Staatsbuch“ (1930). Historia Scholastica. Vol. 1, No. 1, pp. 57-69. ISSN 2336-680X.

REBELLATO, Elisa, ed., 2008. Mondadori. Catalogo storico dei libri per la scuola (19101945). Milano: Franco Angeli. ISBN 978-88-568-0109-5.

RICUPERATI, Giuseppe, 1975. La scuola italiana durante il fascismo. Rivista di storia contemporanea. No. 4, pp. 481-505. ISSN 0391-4240.

SANI, Roberto, 2008. The "Fascist reclamation" of textbooks from the Gentile reform to the School Charter of Bottai. History of Education \& Children's Literature. Vol. 3, No. 2, pp. 305-335. ISSN 1971-1093 (print)/ISSN 1971-1131 (online).

TURI, Gabriele, 1995. Giovanni Gentile. Una biografia. Firenze: Giunti. ISBN 88-09-207556. 